\title{
PENINGKATAN HASIL BELAJAR SISWA DALAM PEMBELAJARAN PKn DENGAN MENGGUNAKAN MODEL KOOPERATIF TIPE TPS DI SEKOLAH DASAR
}

\author{
Wulandari Addha $^{1)}$, Dra. Reinita, M.Pd ${ }^{2)}$, Dra. Harni, M.Pd ${ }^{3)}$ \\ ${ }^{1)}$ Mahasiswa, Universitas Negeri Padang, Indonesia \\ ${ }^{2)}$ Pembimbing 1, Universitas Negeri Padang, Indonesia \\ ${ }^{3)}$ Pembimbing 2, Universitas Negeri Padang, Indonesia \\ ${ }^{1)}$ wulan.addha10@gmail.com, ${ }^{2)}$ reinita_reinita@yahoo.com, \\ ${ }^{3)}$ harnihps@gmail.com
}

\begin{abstract}
Abstrak
Tujuan dari penelitian ini adalah mendeskripsikan peningkatan hasil belajar PKn dengan menggunakan model kooperatif tipe TPS di Kelas IV SDN 52 Kuranji Kota Padang. Penelitian ini menggunakan pendekatan kualitatif dan kuantitatif dengan jenis penelitian tindakan kelas (PTK). Subjek penelitian adalah guru dan 20 orang siswa. Hasil penelitian pada perencanaan siklus I rata-rata $78,57 \%$ meningkat pada siklus II 92,85\%. Hasil penelitian dari aspek guru siklus I 78,12\% meningkat pada siklus II 90,62\%. Hasil penelitian aspek siswa siklus I $76,56 \%$ meningkat pada siklus II $87,50 \%$. Hasil belajar siswa siklus I 76,10 meningkat pada siklus II 86,08.
\end{abstract}

Kata Kunci: PKn, model kooperatif tipe TPS

\section{AN ENHANCEMENT OF THE STUDENT LEARNING RESULT WITHIN CIVILIZATION LEARNING BY USING A COOPERATIVE MODEL TPS TYPE IN ELEMENTARY SCHOOL}

\begin{abstract}
The purpose of this research is cleary describe an improvement of $P K N$ learning result by using cooperative model of TPS type $4^{\text {th }}$ class SDN 52 Kuranji, Padang. This reasearch use a qualitative and quantitative approaches with an action classroom method (PTK). The subjects of a research are a teacher and 20 students. A research result by cycle planning I is about 78,57\% then rises by cycle II about $92,85 \%$. An from teacher side cycle I is about 78,12\% and cycle II rises about 90,62\%. In addition, from student aspect cycle I is about $76,56 \%$ and rises by cycle II about $87,50 \%$. Then the student learning result from cycle I about 76,10 and rises by cycle II 86,08.
\end{abstract}

Keywords: Civics, cooperative model of TPS type

1 | P a g e e-Jurnal Inovasi Pembelajaran SD http://ejournal.unp.ac.id/indek.php/pd 


\section{PENDAHULUAN}

Pendidikan kewarganegaraan (PKn) adalah mata pelajaran yang digunakan sebagai wahana untuk mengembangkan dan melestarikan nilai luhur dan moral yang berakar pada budaya bangsa Indonesia. Pembelajaran PKn di Sekolah Dasar (SD) bertujuan untuk membentuk watak dan karakteristik warga negara yang baik. Sebagaimana yang dijelaskan oleh Depdiknas (2006:271) tujuan PKn adalah untuk menjadikan siswa agar:

1)Berpikir secara kritis, rasional dan kreatif dalam menanggapi isu kewarganegaraan, 2) Berpartisipasi secara aktif dan bertanggung jawab dan bertindak secara cerdas dalam kegiatan bermasyarakat, berbangsa, bernegara dan anti korupsi, 3) Berkembang secara positif dan demokratis untuk membentuk diri berdasarkan karakterkarakter masyarakat Indonesia agar dapat hidup bersama dengan bangsabangsa lainnya, 4) Dan berinteraksi dengan bangsa-bangsa lain dalam peraturan dunia secara langsung atau tidak langsung dengan memanfaatkan teknologi, informasi dan komunikasi.

Untuk mewujudkan tujuan pembelajaran PKn di atas, dimana guru dalam pelaksanaan pembelajaran PKn lebih profesional. Guru berada pada titik pusat untuk mengatur, mengarahkan, dan menciptakan pembelajaran untuk mencapai tujuan pendidikan pembelajaran PKn. Secara tidak langsung guru dituntut untuk lebih kreatif dan inovatif dalam melaksanakan pembelajaran. Oleh sebab itu dalam menyajikan materi pembelajaran dan supaya pembelajaran berpusat pada siswa maka guru berusaha melibatkan siswa secara aktif dan memancing siswa agar berpikir secara kritis, rasional dan kreatif dalam proses pembelajaran PKn.

Dalam pembelajaran PKn di SD seharusnya tidak hanya sekedar diajarkan, namun diberi kesempatan pada siswa untuk menemukan dan memecahkan masalah yang berhubungan dengan pembelajaran PKn. Dengan begitu siswa dapat berpikir sendiri sehingga memperoleh pengalaman yang nantinya dapat diterapkan dalam kehidupan sehari-hari.

Berdasarkan hasil observasi yang peneliti lakukan pada tanggal $18 \mathrm{~s} / \mathrm{d} 25 \mathrm{Juli}$ 2017 hasil belajar siswa pada pembelajaran PKn di kelas IV SDN 52 Kuranji Kota Padang masih rendah. Rendahnya nilai siswa di SDN

52 Kuranji Kota Padang disebabkan oleh beberapa permasalahan dalam kegiatan pembelajaran PKn. Permasalahan yang ditemui dari segi guru yaitu; 1) Guru kurang mempedomani RPP dalam pelaksanaan pembelajaran $\mathrm{PKn}$, dimana terlihat dalam kegiatan di RPP guru melakukan tanya jawab dengan siswa pada awal pembelajaran dan siswa dibimbingan oleh guru untuk melakukan penyimpulan materi pembelajaran pada akhir pembelajaran, namun pada prakteknya kegiatan tersebut kurang diterapkan oleh guru dan saat observasi dilakukan materi pelajaran yang diajarkan guru yakni dengan standar kompetensi 1. Memahami sistem pemerintahan desa dan pemerintahan kecamatan, kompetensi dasar 1.1. Mengenal lembaga-lembaga dalam susunan pemerintahan desa dan pemerintahan kecamatan, 2) Guru cenderung lebih menekankan pada penyampaian materi 
pembelajaran PKn saja, 3) Guru kurang menggali pengetahuan siswa dengan mengajukan pertanyaan terkait dengan materi pelajaran yang akan diajarkan, 4) Guru kurang memberikan waktu kepada siswa untuk melatih mengeluarkan pendapat sebelum berbagi dengan kelompok kecil atau kelas secara keseluruhan.

Proses pembelajaran yang dilakukan guru tersebut berdampak pada siswa yaitu; 1) Kurangnya minat belajar siswa sehingga siswa cenderung hanya diam dan memperhatikan guru dalam menyampaikan materi pelajaran,

2) Siswa kurang terlatih berfikir secara kritis dan kreatif dalam pembelajaran PKn untuk meningkatkan kemampuan berkomunikasi dalam menyampaikan pendapat, sehingga siswa menganggap bahwa pembelajaran PKn itu membosankan, 3) Siswa kurang berinteraksi dan berpartisipasi secara aktif dalam pembelajaran PKn, dimana pada saat kegiatan tanya jawab siswa jarang bertanya tentang materi pembelajaran yang telah diberikan guru, sementara apabila guru mengajukan pertanyaan mengenai materi pembelajaran yang telah disampaikan, sebagian besar siswa kurang mampu menjawab pertanyaan yang diajukan guru, 4) Belum terlihat kerja sama antar siswa di dalam kelompok, dimana siswa hanya mengandalkan teman dalam kelompoknya untuk menyelesaikan tugas yang diberikan guru.

Hal di atas berdampak pada hasil belajar siswa, dimana nilai rata-rata ujian tengah semester yang nilai ketuntasannya masih rendah yakni sekitar $30 \%$, dan sekitar $70 \%$ siswa belum tuntas.
Berdasarkan permasalahan yang peneliti temui saat observasi maka untuk meningkatkan hasil belajar siswa pada pembelajaran PKn di SDN 52 Kuranji, guru sebaiknya menggunakan model pembelajaran yang dapat memancing minat dan kreatifitas belajar siswa dalam berpikir yang sesuai dengan materi pelajaran yang akan diajarkan. Dengan menggunakan model pembelajaran diharapkan dapat meningkatkan proses berpikir siswa dan dapat melatih kemampuan siswa dalam mengeluarkan pendapat. Salah satu model pembelajaran yang cocok digunakan dalam pembelajaran PKn adalah model pembelajaran kooperatif. Model pembelajaran kooperatif menurut Asma (2009:2) merupakan "Salah satu model pembelajaran yang terstruktur dan sistematis, dimana kelomok-kelompok kecil bekerja sama untuk mencapai tujuan-tujuan bersama."

Salah satu tipe pembelajaran kooperatif adalah tipe Think Pair and Share (TPS). Tipe TPS merupakan salah satu tipe pembelajaran kooperatif yang dikembangkan oleh Frank Lyman, dkk dari Universitas Maryland pada tahun 1985. Model pembelajaran ini merupakan satu cara yang efektif untuk membuat variasi suasana pola diskusi berpasangan yang dilanjutkan dengan diskusi pleno sehingga memberi siswa kesempatan untuk berpikir sendiri serta bekerja sama dengan orang lain.

Menurut Shoimin (2014:208) bahwa:

Think pair and share adalah model pembelajaran kooperatif yang memberi siswa waktu untuk berpikir dan merespon serta saling bantu satu sama lain. Model ini memperkenalkan ide 


\section{e-Jurnal Inovasi Pembelajaran SD \\ Volume 6, No 1, 2018}

"waktu berpikir atau waktu tunggu" yang menjadi faktor kuat dalam meningkatkan kemampuan siswa dalam merespon pertanyaan. Pembelajaran dengan menggunakan model think pair and share ini relatif lebih sederhana karena tidak menyita waktu yang lama untuk mengatur tempat duduk ataupun mengelompokkan siswa. Dengan menggunakan model ini dapat melatih siswa untuk berani berpendapat dan menghargai pendapat teman.

Dengan menggunakan model pembelajaran kooperatif tipe TPS dalam pembelajaran PKn maka dapat terjadi interaksi antar siswa, bekerja sama, melatih siswa untuk berani berpendapat dalam kelompok kecil serta pembelajaran lebih berpusat pada siswa.

Berdasarkan kelebihan dari model Kooperatif tipe TPS dan permasalahan yang peneliti temukan di lapangan pada saat melakukan observasi di kelas IV, maka peneliti tertarik melakukan penelitian tindakan kelas dengan judul "Peningkatan Hasil Belajar Siswa dalam Pembelajaran PKn dengan Menggunakan Model Kooperatif Tipe Think Pair Share (TPS) di Kelas IV SDN 52 Kuranji Kota Padang."

Penelitian ini dirancang untuk mendeskripsikan peningkatan hasil belajar siswa dalam pembelajaran PKn dengan menggunakan model kooperatif tipe TPS di kelas IV SDN 52 Kuranji Kota Padang.

\section{METODE PENELITIAN}

Jenis penelitian yang peneliti lakukan adalah penelitian tindakan kelas. Penelitian tindakan kelas merupakan penelitian yang dilakukan guru di kelasnya dengan tujuan memperbaiki kinerjanya sebagai guru. Menurut Kunandar (2011:46), “Penelitian tindakan kelas adalah suatu kegiatan ilmiah yang dilakukan oleh guru di kelasnya sendiri dengan jalan merancang, melaksanakan, mengamati dan merefleksikan tindakan melalui beberapa siklus secara kolaboratif dan partisipasif yang bertujuan untuk memperbaiki atau meningkatkan mutu proses pembelajaran di kelasnya."

Penelitian ini dilaksanakan pada semester I tahun ajaran 2017/2018. Penelitian ini dilaksanakan dalam dua siklus yaitu siklus I pertemuan I dilaksanakan pada tanggal 3 Oktober 2017, siklus I pertemuan II dilaksanakan pada tanggal 10 Oktober 2017 dan siklus II dilaksanakan pada tanggal 17 Oktober 2017. Sumber data penelitian adalah proses pembelajaran $\mathrm{PKn}$ dengan menggunakan model kooperatif tipe TPS di kelas IV SD yang meliputi: perencanaan pembelajaran, pelaksanaan pembelajaran yang terdiri dari kegiatan awal, kegiatan inti dan kegiatan akhir, kegiatan evaluasi pembelajaran, aktivitas guru dan siswa sewaktu proses pembelajaran. Data penelitian yang dikumpulkan dengan menggunakan teknik observasi, dan tes. Agar tujuan penelitian ini tercapai digunakan instrumen penelitian yaitu lembar observasi dan lembar tes. Lembar observasi digunakan untuk mengamati kegiatan yang dilakukan guru dan siswa dalam proses pembelajaran PKn. Sedangkan lembar tes yang digunakan untuk melihat hasil belajar siswa. Alat yang digunakan dalam tes adalah berupa butir-butir soal untuk mengukur hasil belajar siswa.

Data dalam penelitian ini menggunakan data kualitatif dan data kuantitatif. Data 


\section{e-Jurnal Inovasi Pembelajaran SD \\ Volume 6, No 1, 2018}

kualitatif berupa analisis data yang dilakukan dengan menelaah data sejak pengumpulan sampai semua data telah terkumpul. Data yang di peroleh dalam penelitian ini akan di analisis menggunakan analisis data kualitatif menurut Milles (dalam Kunandar 2011:101) yakni, "Analisis data dimulai dengan menelaah sejak pengumpulan data sampai seluruh data terkumpul". Data tersebut direduksi berdasarkan masalah yang diteliti diikuti penyajian data dan terakhir penyimpulan. Tahap analisis demikian dilakukan berulang- ulang begitu data selesai dikumpulkan pada setiap pengumpulan dalam setiap tindakan. Sedangkan analisis data kuantitatif terhadap hasil belajar siswa dengan menggunakan rumus persentase yang dikemukakan oleh Purwanto (2013:102) sebagai berikut:

Keterangan :

NP : Nilai presentase yang diharapkan

R : Skor yang diperoleh siswa

SM : Skor maksimum ideal dari tes yang bersangkutan

100 : Bilangan tetap

Kriteria rentangan nilai dari persentase data yang diperoleh menurut Purwanto (2013:103) ditentukan sebagai berikut:

$\begin{array}{ll}\text { Sangat baik } & : 86-100 \% \\ \text { Baik } & : 76-85 \% \\ \text { Cukup } & : 60-75 \% \\ \text { Kurang } & : \leq 59 \%\end{array}$

Sementara itu persentase ketuntasan belajar menurut Kunandar (2011:149) adalah: "Persentase ketuntasan belajar setiap Kompetensi Dasar (KD) berkisar antara 0$100 \%$. Kriteria ideal ketuntasan untuk masingmasing Kompetensi Dasar adalah 75\%, maksudnya jika persentase ketuntasan sudah mencapai $75 \%$ barulah pembelajaran itu bisa dikatakan berhasil."

\section{HASIL DAN PEMBAHASAN \\ SIKLUS I}

Pada siklus I penelitian dilakukan $2 \mathrm{x}$ pertemuan. Pertemuan I dilaksanakan pada hari selasa tanggal 3 Oktober 2017. Pertemuan II dilaksanakan pada hari selasa tanggal 10 Oktober 2017. Penelitian dilakukan sesuai dengan alur yang telah dibuat, yaitu: 1) perencanaan, 2) pelaksanaan, 3) pengamatan, dan 4) refleksi. Hal tersebut dapat dideskripsikan sebagai berikut :

\section{Perencanaan}

Sebelum pelaksanaan pembelajaran terlebih dahulu peneliti mempersiapkan rencana pelaksanaan pembelajaran, LDK, lembar kunci LDK, lembar evaluasi serta kunci jawaban evaluasi yang akan digunakan dalam pembelajaran. Di samping itu peneliti juga mempersiapkan lembar pengamaatan untuk mengamati jalannya pembelajaran. Perencanaan ini disusun dan dikembangkan berdasarkan program semester I Standar Kompetensi yang akan diambil adalah: 2. Memahami sistem pemerintahan kabupaten, kota dan provinsi. Kompetensi Dasar adalah

2.1. Mengenal lembaga-lembaga dalam susunan pemerintahan kabupaten, kota dan provinsi. 


\section{e-Jurnal Inovasi Pembelajaran SD}

Volume 6, No 1, 2018

\section{Pelaksanaan}

Proses pelaksanaan pada siklus I, baik pertemuan I maupun pertemuan II pembelajaran berlangsung selama $2 \times 35$ menit. Kegiatan yang dilaksanakan ialah langkah pertama dari model kooperatif tipe TPS yaitu berpikir (thinking), yakni Guru mengajukan pertanyaan kepada siswa yang berkaitan dengan pelajaran yaitu lembaga pemerintahan kabupaten/kota. Kemudian siswa diminta memikirkan pertanyaan atau isu tersebut secara mandiri untuk beberapa saat.

Langkah kedua berpasangan (pairing), yakni Guru meminta siswa berpasangan dengan siswa lain untuk mendiskusikan apa yang telah dipikirkannya tentang materi lembaga pemerintahan kabupaten/kota. Dalam tahap ini, setiap anggota pada kelompok membandingkan jawaban atau hasil pemikiran mereka dengan merumuskan jawaban yang dianggap paling benar atau paling meyakinkan.

Langkah ketiga berbagi (sharing), yakni guru meminta kepada pasangan untuk berbagi dengan seluruh kelas tentang apa yang telah mereka bicarakan. Tiap pasangan bergiliran melaporkan apa yang telah mereka diskusikan hingga sekitar sebagian pasangan.

\section{Pengamatan}

Hasil pengamatan pada siklus I dilakukan terhadap RPP, aspek guru, aspek siswa, dan hasil belajar siswa. baik pertemuan I maupun pertemuan II. Berikut ini adalah hasil pengamatan siklus I: pengamatan RPP pertemuan I perolehan persentase $75 \%$ pada pertemuan II perolehan persentase $82,14 \%$ dengan rata-rata perolehan persentase siklus I yaitu $78,57 \%$ dengan kualifikasi baik.
Pengamatan terhadap pelaksanaan aspek guru pertemuan I perolehan persentase $71,87 \%$ pada pertemuan II perolehan persentase $84,37 \%$ dengan rata-rata perolehan persentase siklus I yaitu $78,12 \%$ dengan kualifikasi baik. Pengamatan terhadap pelaksanaan aspek siswa pertemuan I perolehan persentase $71,87 \%$ pada pertemuan II perolehan persentase $81,25 \%$ dengan rata-rata perolehan siklus I yaitu 76,56\% dengan kualifikasi baik. Hasil belajar yang diperoleh siswa pertemuan I yaitu 72,85 pertemuan II yaitu 79,36 dengan rata-rata hasil belajar siklus I yaitu 76,10 dengan kualifikasi baik.

\section{Refleksi}

Kegiatan refleksi dilakukan secara kolaboratif antara peneliti dengan observer di setiap akhir pembelajaran. Sesuai hasil diskusi peneliti dengan guru kelas, terdapat kekurangan-kekurangan pada siklus I. kekurangan-kekurangan yang terdapat pada siklus I ini diperbaiki pada siklus II dan yang sudah dicapai dapat dipertahankan serta ditingkatkan, agar tujuan yang diharapkan tercapai dengan maksimal.

\section{Siklus II}

Pada siklus II penelitian hanya dilakukan $1 \quad x \quad$ pertemuan. Siklus II dilaksanakan pada hari selasa tanggal 17 Oktober 2017. Penelitian pada siklus II masih sama seperti yang ada di siklus I, yaitu dimulai dari: 1) perencanaan, 2) pelaksanaan, 3) pengamatan, dan 4) refleksi. Hal tersebut dapat dideskripsikan sebagai berikut :

\section{Perencanaan}

Sebelum pelaksanaan pembelajaran terlebih dahulu peneliti mempersiapkan 


\section{e-Jurnal Inovasi Pembelajaran SD \\ Volume 6, No 1, 2018}

rencana pelaksanaan pembelajaran, LDK, lembar kunci LDK, lembar evaluasi serta kunci jawaban evaluasi yang akan digunakan dalam pembelajaran. Di samping itu peneliti juga mempersiapkan lembar pengamaatan untuk mengamati jalannya pembelajaran.

Perencanaan ini disusun dan dikembangkan berdasarkan program semester I Standar Kompetensi yang akan diambil adalah: 2. Memahami sistem pemerintahan kabupaten, kota dan provinsi. Kompetensi Dasar adalah 2.1. Mengenal lembaga-lembaga dalam susunan pemerintahan kabupaten, kota dan provinsi.

\section{Pelaksanaan}

Proses pelaksanaan pada siklus I, baik pertemuan I maupun pertemuan II pembelajaran berlangsung selama $2 \times 35$ menit. Kegiatan yang dilaksanakan ialah langkah pertama dari model kooperatif tipe TPS yaitu berpikir (thinking), yakni Guru mengajukan pertanyaan kepada siswa yang berkaitan dengan pelajaran yaitu lembaga pemerintahan kabupaten/kota. Kemudian siswa diminta memikirkan pertanyaan atau isu tersebut secara mandiri untuk beberapa saat.

Langkah kedua berpasangan (pairing), yakni Guru meminta siswa berpasangan dengan siswa lain untuk mendiskusikan apa yang telah dipikirkannya tentang materi lembaga pemerintahan kabupaten/kota. Dalam tahap ini, setiap anggota pada kelompok membandingkan jawaban atau hasil pemikiran mereka dengan merumuskan jawaban yang dianggap paling benar atau paling meyakinkan.

Langkah ketiga berbagi (sharing), yakni guru meminta kepada pasangan untuk berbagi dengan seluruh kelas tentang apa yang telah mereka bicarakan. Tiap pasangan bergiliran melaporkan apa yang telah mereka diskusikan hingga sekitar sebagian pasangan.

\section{Pengamatan}

Hasil pengamatan pada siklus I dilakukan terhadap RPP, aspek guru, aspek siswa, dan hasil belajar siswa. baik pertemuan I maupun pertemuan II. Berikut ini adalah hasil pengamatan siklus II: pengamatan RPP perolehan persentase $92,85 \%$ dengan kualifikasi sangat baik. Pengamatan terhadap pelaksanaan aspek guru perolehan persentase 90,62\% dengan kualifikasi sangat baik. Pengamatan terhadap pelaksanaan aspek siswa perolehan persentase $87,50 \%$ dengan kualifikasi sangat baik. Hasil belajar yang diperoleh siswa siklus I yaitu 86,08.

\section{Refleksi}

Kegiatan refleksi dilakukan secara kolaboratif antara peneliti dengan observer di setiap akhir pembelajaran. Berdasarkan hasil pengamatan yang dilakukan oleh observer menunjukkan bahwa pelaksanaan pembelajaran menggunakan model kooperatif tipe TPS sudah terlaksana dengan baik walaupun masih terdapat beberapa kekurangan. Jadi, dapat disimpulkan pembelajaran pada siklus II ini telah berjalan sesuai dengan yang direncanakan dan tingkat ketuntasan untuk kelas telah sesuai dengan apa yang diharapkan. Maka penelitian ini sudah dapat dikatakan berhasil. Dengan demikian, pelaksanaan tindakan kelas diakhiri pada siklus II

\section{Siklus I}

\section{Perencanaan}




\section{e-Jurnal Inovasi Pembelajaran SD \\ Volume 6, No 1, 2018}

Hasil penelitian peningkatan hasil belajar siswa dalam pembelajaran PKn dengan menggunakan model kooperatif tipe TPS di kelas IV SDN 52 Kuranji Kota Padang pada siklus I, dalam pembahasan perencanaan tindakan terungkap bahwa dalam melaksanakan pembelajaran, sebelumnya guru telah membuat rancangan pembelajaran dalam bentuk RPP. RPP ini menjadi acuan dari kegiatan yang akan diterapkan atau dilaksanakan selama proses pembelajaran.

Berdasarkan hasil pengamatan yang dilakukan oleh observer, pada siklus I terdapat beberapa kekurangan diantaranya: pengorganisasian materi ajar belum sesuai dengan alokasi waktu. Sebaiknya guru dapat memperhatikan alokasi waktu dalam mengorganisasikan materi ajar agar materi yang dipelajari siswa dapat tersampaikan dengan baik. Selanjutnya belum mutakhir (sesuai dengan perkembangan di bidangnya), sebaiknya hal ini juga menjadi pertimbangan guru dan guru dapat memperhatikan perkembangan terakhir sesuai dengan materi ajar.

Pada kejelasan proses pembelajaran, langkah-langkah pembelajaran belum sesuai dengan alokasi waktu. Sebaiknya guru bisa membagi waktu agar setiap langkah terlaksana dengan baik dan sesuai dengan waktu yang sudah ditetapkan. Selanjutnya, dalam teknik pembelajaran belum sesuai dengan lingkungan sekolah dan lingkungan siswa. Sebaiknya, guru lebih memperhatikan bagaimana lingkungan sekolah dan lingkungan siswa agar kegiatan pembelajaran dapat berjalan dengan baik.
Pada siklus I ini, RPP yang telah disusun oleh peneliti belum sepenuhnya terlaksana dengan baik dalam kegiatan pembelajaran. Padahal fungsi dari RPP bagi guru agar pelaksanaan kegiatan pembelajaran menjadi terararah dan berjalan sesuai dengan yang sudah direncanakan. Hal ini sesuai dengan pernyataan Kunandar (2011:264), "Fungsi rencana pembelajaran adalah sebagai acuan bagi guru untuk melaksanakan kegiatan pembelajaran agar lebih terarah dan berjalan secara efektif dan efisien." Berdasarkan hal tersebut peneliti perlu melanjutkan ke siklus selanjutnya, dan lebih meningkatkan penerapan RPP sebagai acuan dalam kegiatan pembelajaran.

\section{Pelaksanaan}

Pelaksanaan pembelajaran pada siklus I sesuai dengan apa yang telah direncanakan. Pembelajaran pada siklus I ini disajikan dalam dua kali pertemuan, setiap pertemuan dengan alokasi waktu 2 x 35 menit. Hasil pengamatan yang dilakukan oleh obsever, ditemukan beberapa kekurangan dalam pelaksanaan kegiatan pembelajaran diantaranya: menyampaikan tujuan pembelajaran belum sesuai dengan tingkat perkembangan siswa. Sebaiknya saat guru menyampaikan tujuan pembelajaran disesuaikan dengan tingkat perkembangan siswa sehingga siswa memahami tujuan pembelajaran yang akan dicapai pada pembelajaran tersebut.

Pada kegiatan appersepsi, guru belum memberikan pertanyaan yang jelas. Sebaiknya guru memberikan pertanyaan yang jelas agar pertanyaan yang diberikan tidak membingungkan siswa. Dalam langkah 


\section{e-Jurnal Inovasi Pembelajaran SD \\ Volume 6, No 1, 2018}

berbagi, guru belum membimbing siswa bertanya dan berargumen saat berlangsungnya diskusi dan meluruskan jawaban siswa yang keliru. Sebaiknya kegiatan ini dilakukan agar langkah TPS terlaksana dan tercapai tujuan pembelajaran. Selanjutnya pada konfirmasi, guru belum menanyakan materi yang diragukan siswa. Sebaiknya kegiatan ini dilakukan agar siswa lebih mengerti dan paham akan pelajaran saat itu.

Berdasarkan pelaksanaan pada siklus I ini, dapat diketahui bahwa pelaksanaan pembelajaran belum berjalan dengan baik sebagaimana pelaksanaan pembelajaran dengan menggunakan model kooperatif tipe TPS yang dikemukakan oleh Trianto (2009:81-82) yakni:

1) Berpikir (thinking) yaitu, guru mengajukan suatu pertanyaan atau masalah yang dikaitkan dengan pelajaran, dan meminta siswa menggunakan waktu beberapa menit untuk berpikir sendiri jawaban atau masalah, 2) Berpasangan (pairing) yaitu guru meminta siswa untuk berpasangann dan mendiskusikan apa yang telah mereka peroleh. Interaksi selama waktu yang disediakan dapat menyatukan jawaban, 3) Berbagi (sharing), pada langkah terakhir, guru meminta pasangan-pasangan untuk berbagi dengan keseluruhan kelas yang telah mereka bicarakan.

Dengan demikian peneliti perlu melanjutkan ke siklus berikutnya, agar pelaksanaan pembelajaran dengan menggunakan model kooperatif tipe TPS berjalan sebagaimana mestinya.

\section{Hasil belajar}

Untuk memperoleh hasil belajar siswa dilakukan penilaian terlebih dahulu. Penilaian yang dilakukan oleh guru meliputi tiga ranah yaitu ranah kognitif, afektif dan psikomotor. Ketiga ranah tersebut menjadi objek penilaian hasil belajar.

Pelaksanaan evaluasi dilaksanakan pada siklus I pertemuan I dan II. Berdasarkan hasil belajar siswa pada siklus I, maka proses pembelajaran PKn dengan menggunakan model kooperatif tipe TPS belum mencapai target seperti yang diharapkan. Karena masih banyak siswa yang mendapatkan nilai di bawah KKM. Dari ranah kognitif rata-rata nilai siswa dari kedua pertemuan mencapai 75,62 dari ranah afektif 77,71 dan dari ranah psikomotor 77,08. Rata-rata dari ketiga ranah tersebut adalah 76,10.

Berdasarkan nilai yang diperoleh pada siklus I ini, belum terlihat adanya perubahan yang terlalu signifikan, karena masih banyak siswa yang belum mencapai ketuntasan, sesuai yang dikemukakan oleh Hamalik (2011:155), "Hasil belajar tampak sebagai terjadinya perubahan tingkah laku pada diri siswa, yang dapat diamati dan diukur dalam bentuk perubahan pengetahuan, sikap dan keterampilan. Dengan demikian, peneliti perlu melanjutkan penelitian ke siklus berikutnya, agar proses pembelajaran lebih ditingkatkan dan nilai yang diperoleh siswa mencapai standar ketuntasan belajar.

\section{Siklus II}

\section{Perencanaan}

Peneliti melakukan perencanaan tindakan pada siklus II ini dengan berkolaborasi bersama observer. Setiap kekurangan yang ditemukan pada pelaksanaan siklus I menjadi faktor penting yang harus 


\section{e-Jurnal Inovasi Pembelajaran SD \\ Volume 6, No 1, 2018}

diperhatikan dalam menyusun perencanaan tindakan pada siklus II.

Berdasarkan hasil pengamatan yang dilakukan oleh observer, pada siklus II terdapat beberapa kekurangan diantaranya: pengorganisasian materi ajar belum sesuai dengan alokasi waktu. Sebaiknya guru dapat memperhatikan alokasi waktu dalam mengorganisasikan materi ajar agar materi yang dipelajari siswa dapat tersampaikan dengan baik. Selanjutnya, dalam teknik pembelajaran belum sesuai dengan lingkungan siswa. Sebaiknya, guru lebih memperhatikan bagaimana lingkungan siswa agar kegiatan pembelajaran dapat berjalan dengan baik.

Pada rencana pelaksanaan pembelajaran di siklus II ini sudah sesuai dengan yang diharapkan sehingga pembelajaran menjadi lebih terarah dan berjalan dengan baik. Hal ini sesuai dengan pernyataan Kunandar (2011:264), "Fungsi rencana pembelajaran adalah sebagai acuan bagi guru untuk melaksanakan kegiatan pembelajaran agar lebih terarah dan berjalan secara efektif dan efisien." Oleh karena itu, peneliti tidak perlu melanjutkan ke siklus selanjutnya.

\section{Pelaksanaan}

Pelaksanaan pembelajaran pada siklus II sesuai dengan apa yang telah direncanakan. Pembelajaran pada siklus II ini disajikan dalam satu kali pertemuan dengan alokasi waktu $2 \times 35$ menit.

Hasil pengamatan yang dilakukan oleh obsever, ditemukan beberapa kekurangan dalam pelaksanaan kegiatan pembelajaran diantaranya: menyampaikan tujuan pembelajaran belum sesuai dengan tingkat perkembangan siswa. Sebaiknya saat guru menyampaikan tujuan pembelajaran disesuaikan dengan tingkat perkembangan siswa sehingga siswa memahami tujuan pembelajaran yang akan dicapai pada pembelajaran tersebut. Selanjutnya pada konfirmasi, guru belum meluruskan pemahaman siswa terhadap konsep materi pelajaran. Sebaiknya kegiatan ini dilakukan agar siswa lebih mengerti dan paham akan pelajaran saat itu.

Berdasarkan pelaksanaan pada siklus I ini, dapat diketahui bahwa pelaksanaan pembelajaran sudah berjalan dengan baik sebagaimana pelaksanaan pembelajaran dengan menggunakan model kooperatif tipe TPS yang dikemukakan oleh Trianto (2009:81-82) yakni:

1) Berpikir (thinking) yaitu, guru mengajukan suatu pertanyaan atau masalah yang dikaitkan dengan pelajaran, dan meminta siswa menggunakan waktu beberapa menit untuk berpikir sendiri jawaban atau masalah, 2) Berpasangan (pairing) yaitu guru meminta siswa untuk berpasangann dan mendiskusikan apa yang telah mereka peroleh. Interaksi selama waktu yang disediakan dapat menyatukan jawaban, 3) Berbagi (sharing), pada langkah terakhir, guru meminta pasangan-pasangan untuk berbagi dengan keseluruhan kelas yang telah mereka bicarakan.

Dengan demikian peneliti tidak melanjutkan ke siklus berikutnya, karena pelaksanaan pembelajaran dengan menggunakan model kooperatif tipe TPS berjalan sebagaimana mestinya. 


\section{Hasil belajar}

Pelaksanaan evaluasi dilaksanakan pada siklus II. Berdasarkan hasil belajar siswa pada siklus II, telah mengalami peningkatan dari siklus sebelumnya dan telah mencapai target yang diharapkan. Dari ranah kognitif rata-rata nilai siswa mencapai 88,25 dari ranah afektif 86,67 dan dari ranah psikomotor 83,33. Ratarata dari ketiga ranah tersebut adalah 86,08. Berdasarkan nilai yang diperoleh pada siklus II ini, maka proses pembelajaran telah mengalami perubahan dan peningkatan. Nilai yang diperoleh siswa telah mencapai tingkat ketuntasan.

\section{SIMPULAN}

Hasil penelitian menunjukkan bahwa pengamatan terhadap RPP pada siklus I pertemuan I memperoleh persentase $75 \%$ dengan kualifikasi cukup, pada pertemuan II memperoleh persentase $82,14 \%$ dengan kualifikasi baik, meningkat pada siklus II yaitu 92,85\% dengan kualifikasi sangat baik. Berdasarkan hasil pengamatan dari aspek guru siklus I pertemuan I memperoleh persentase $71,87 \%$ dengan kualifikasi cukup, pada pertemuan II memperoleh persentase $84,37 \%$ dengan kualifikasi baik dan siklus II memperoleh persentase $90,62 \%$ dengan kualifikasi sangat baik. Dari aspek siswa siklus I perolehan persentase $71,87 \%$ dengan kualifikasi cukup, pertemuan II perolehan persentase $81,25 \%$ dengan kualifikasi baik dan siklus II perolehan persentase $87,50 \%$ dengan kualifikasi sangat baik. Hasil belajar siswa, pada siklus I pertemuan I diperoleh persentase 72,85 , pada pertemuan II diperoleh persentase
79,36 dan pada siklus II mengalami peningkatan menjadi 86,08 .

Berkenaan dengan hasil penelitian, peneliti mengemukakan beberapa saran yang sekiranya dapat memberikan masukan untuk dapat meningkatkan hasil belajar siswa yaitu:

1) Diharapkan guru hendaknya dapat membuat rancangan pembelajaran dengan menggunakan model kooperatif tipe TPS dalam pembelajaran PKn agar pembelajaran berlangsung efektif dan efisien, 2) Diharapkan guru dalam pelaksanaan pembelajaran $\mathrm{PKn}$ dengan menggunakan model kooperatif tipe TPS. Disamping itu guru dapat membimbing siswa dalam langkah berpikir (thinking), berpasangan (pairing), dan berbagi (sharing), sehingga pembelajaran diharapkan tercapai dengan baik, 3) Diharapkan hasil belajar siswa dapat meningkat menggunakan model kooperatif tipe TPS dalam pembelajaran PKn.

\section{DAFTAR RUJUKAN}

Depdiknas. (2006). Kurikulum Tingkat Satuan Pendidikan. Jakarta: Depdiknas.

Asma, Nur. 2009. Model Pembelajaran Kooperatif. Padang: UNP Press.

Hamalik, Oemar. (2011). Proses Belajar Mengajar. Jakarta: Bumi Aksara.

Kunandar. (2011). Penelitian Tindakan Kelas. Jakarta: Rajawali Pers.

_ _ _ . (2011). Guru Profesional Implementasi Kurikulum Tingkat Satuan Pendidikan (KTSP) dan Sukses dalam Sertifikasi Guru. Jakarta: Rajawali Pers.

Purwanto, Ngalim. (2013). Prinsip-prinsip dan Teknik Evaluasi Pengajaran. Bandung: PT.Remaja Rosdakarya. 
e-Jurnal Inovasi Pembelajaran SD

Volume 6, No 1, 2018

Shoimin,Aris. (2014). 68 Model Pembelajaran

Inovatif dalam Kurikulum 2013.

Yogyakarta: Ar-Ruzz Media.

Trianto. (2009). Mendesain Model

Pembelajaran Inovatif-Progresif.

Jakarta: Kencana Prenada Media

Group.

12 | P a g e e-Jurnal Inovasi Pembelajaran SD http://ejournal.unp.ac.id/indek.php/pd 